\title{
PEMBERIAN AROMATERAPI MINYAK PEPPERMINT SECARA INHALASI BERPENGARUH TERHADAP PENURUNAN MUAL MUNTAH PADA IBU HAMIL DI PMB LINDA SILALAHI PANCUR BATU TAHUN 2019
}

\author{
Rismahara Lubis ${ }^{1}$,Sonya Evita, ${ }^{2}$ Yusniar Siregar ${ }^{1}$ \\ ${ }^{1}$ Dosen Poltekkes Kemenkes Medan Jurusan Kebidanan Medan \\ ${ }^{2}$ Mahasiswa Poltekkes Kemenkes Medan Jurusan Kebidanan \\ Jl. Jamin Ginting Km.13.5 Kelurahan Lau Cih, Medan Tuntungan, Sumatera Utara \\ Email: ${ }^{1}$ sonyaevita@gmail.com, ${ }^{2}$ rismaharalubis@gmail.com, ${ }^{3}$ yusniarsiregar@yahoo.com
}

\section{PROVISION OF PEPPERMINT OIL AROMATERAPY INFLUENCE AGAINST REDUCTION OF VOMITINGIN PREGNANT MOTHER IN LINDA SILALAHI PMB PANCUR BATU IN 2019}

\begin{abstract}
Feelings of nausea and vomiting are one of the discomforts that are often found in pregnancy and which usually occur early in pregnancy. The handling of vomiting and nausea can be done through non-pharmacological therapy in the form of peppermint oil inhaled aromatherapy that is noninstructive, non-invasive, inexpensive, effective and has no side effects. This study aims to determine the effect of peppermint oil inhaled aromatherapy on decreasing the nausea and vomiting in pregnant women at the private clinic of Linda Silalahi Pancur Batu. This research is a preexperimental study designed with one group pretest posttest designs examining 15 pregnant women as samples obtained through purposive sampling techniques. Then the data were analyzed by the Wilcoxon Sign Rank Test and based on the results of the study it was found that before the inhalation of the peppermint oil aromatherapy, majority of the pregnant women experienced moderate nausea, 12 people (80\%), but after the aromatherapy majority of pregnant women did not experience nausea vomiting, 12 people (80\%). It was also found that differences in the mean scores of nausea and vomiting of pregnant women before and after inhalation of peppermint oil aromatherapy were 6.13. Through the Wilcoxon Sign Rank Test obtained p value of 0.001, which means that there is an effect aromatherapy to decrease nausea and vomiting in pregnant women at private clinic of Linda Silalahi Pancur Batu. Pregnant women who experience nausea and vomiting can use peppermint oil inhaled aromatherapy to reduce the use of pharmacological therapy.
\end{abstract}

Keywords : Nausea and Vomiting, Peppermint Aromatherapy

\begin{abstract}
ABSTRAK
Salah satu ketidaknyamanan dalam kehamilan adalah mual muntah yang biasanya terjadi pada awal kehamilan. Keluhan mual muntah terjadi pada $60-80 \%$ primigravida dan $40-60 \%$ pada multigravida. Penatalaksanaan mual muntah dapat dilakukan dengan memberikan terapi nonfarmakologis berupa aromaterapi minyak peppermint secara inhalasi yang bersifat noninstruktif, noninfasif, murah, efektif dan tidak mempunyai efek samping yang merugikan. Tujuan penelitian ini adalah untuk mengetahui pengaruh pemberian aromaterapi minyak peppermint secara inhalasi terhadap penurunan mual muntah pada ibu hamil di PMB Linda Silalahi Pancur Batu. Penelitian ini merupakan penelitian Pra Eksperimental dengan rancangan One Group Pretest Posttest Designs. Sampel berjumlah 15 orang ibu hamil yang diambil dengan teknik Purposive Sampling. Analisis data menggunakan Uji Wilcoxon Sign Rank Test. Hasil penelitian menunjukkan sebelum diberikan aromaterapi minyak peppermint secara inhalasi mayoritas ibu hamil mengalami mual muntah sedang sebanyak 12 orang $(80 \%)$ dan setelah diberikan aromaterapi minyak peppermint secara inhalasi mayoritas ibu hamil tidak mengalami mual muntah sebanyak 12 orang $(80 \%)$. Ada perbedaan nilai rata-rata skor mual muntah ibu hamil sebelum dan sesudah pemberian aromaterapi minyak peppermint secara inhalasi sebesar 6,13. Hasil uji Wilcoxon Sign Rank Test diperoleh nilai $p$ value 0,001 yang artinya ada pengaruh
\end{abstract}


pemberian aromaterapi minyak peppermint secara inhalasi terhadap penurunan mual muntah pada ibu hamil di PMB Linda Silalahi Pancur Batu. Ibu hamil yang mengalami mual muntah dapat menggunakan aromaterapi minyak peppermint secara inhlasi sehingga dapat mengurangi penggunaan terapi farmakologis.

Kata Kunci : Mual Muntah, Aromaterapi Peppermint

\section{PENDAHULUAN}

Perubahan sistem dalam tubuh ibu selama proses kehamilan membutuhkan suatu adaptasi baik fisik maupun psikologis sehingga tidak jarang ibu akan mengalami ketidaknyamanan dalam perubahan tersebut sehingga perlu diberikan suatu pencegahan dan perawatan. Ketidaknyamanan yang terjadi pada ibu hamil meliputi mual muntah, mengidam, nyeri ulu hati, konstipasi, hemorhoid, insomnia, sering buang air kecil, nyeri punggung, bengkak pada kaki, sesak nafas, mudah lelah, dan lain-lain (Farrer, 2001). Ketidaknyamanan tersebut jika tidak ditangani dengan benar dapat memicu terjadinya kecemasan pada ibu hamil. Ibu hamil yang mengalami ketidaknyamanan akan segera mencari pertolongan pertama dengan menjangkau fasilitas pelayanan kesehatan (Eniyanti dan Devi, 2017).

Kunjungan ibu hamil pertama kali (K1) ke fasilitas pelayanan kesehatan seperti Praktek Mandiri Bidan merupakan salah satu cara yang tepat saat ibu hamil mengalami ketidaknyamanan (Eniyanti dan Devi, 2017). Pada tahun 2016, cakupan K1 dan K4 di Kota Medan yakni sebesar 94,4\% dan 89,6\% (Dinas Kesehatan Kota Medan, 2016). Berdasarkan data yang diperoleh dari Badan Penelitian dan Pengembangan Kesehatan Kementerian Kesehatan RI tahun 2013, bidan merupakan tenaga kesehatan yang paling berperan $(87,8 \%)$ dalam memberikan pelayanan kesehatan pada ibu hamil dan fasilitas kesehatan yang banyak dimanfaatkan ibu hamil adalah praktek bidan (52,5\%), Puskesmas/Pustu $(16,6 \%)$ dan Posyandu $(10 \%)$.

Salah satu ketidaknyamanan dalam kehamilan adalah mual muntah yang biasanya terjadi pada awal kehamilan. Keluhan ini biasanya terjadi pada pagi hari, tetapi dapat pula terjadi setiap saat dan malam hari (Prawirohardjo, 2009). Mual muntah secara terus menerus akan menimbulkan berbagai komplikasi pada ibu dan janinnya. Kondisi ibu akan kekurangan nutrisi dan cairan sehingga keadaan fisik ibu menjadi lemah dan lelah, mengakibatkan gangguan asam basa, pneumoni aspirasi, robekan mukosa esofagus, kerusakan hepar dan ginjal. Selain itu pertumbuhan dan perkembangan janin akan terhambat karena nutrisi yang tidak terpenuhi dari ibu (Anasari, 2012).

Jika mual muntah ini dibiarkan terus menerus maka dapat mengakibatkan gangguan fungsi alat-alat vital seperti ginjal dan hati, yang lama-kelamaan akan menimbulkan kematian pada ibu dan janinnya (Manuaba, 2007). Hampir 45\% wanita mengalami muntah pada awal kehamilan dan hingga 90\% wanita mengalami mual (Salmah, 2006). Sebagian besar ibu hamil 70-80\% mengalami mual muntah di pagi hari dan sebanyak 1-2\% dari semua ibu hamil mengalami mual muntah yang berlebihan (Khasanah, 2017).

Menurut World Health Organization (WHO) pada tahun 2015 jumlah kejadian emesis gravidarum mencapai 12,5\% dari jumlah kehamilan di dunia. Di Indonesia terdapat 50-90\% kasus mual muntah yang dialami oleh ibu hamil. Keluhan mual muntah terjadi pada $60-80 \%$ primigravida dan $40-60 \%$ pada multigravida. Satu diantara seribu kehamilan, gejala mual muntah ini menjadi lebih berat (Prawirohardjo, 2005).

Dari hasil penelitian Aril (2012) dalam Khasanah 2017 mual muntah terjadi diseluruh dunia dengan angka kejadian yang beragam yaitu 1-3\% dari seluruh kehamilan di Indonesia, 
0,3\% di Swedia, 0,5\% di California, 0,8\% di Canada, 0,8\% di China, 0,9\% di Norwegia, 2,2\% di Pakistan, $1,9 \%$ di Turki dan di Amerika Serikat prevalensi mual muntah pada ibu hamil adalah 0,5\%-2\%. Diduga 50\% sampai $80 \%$ ibu hamil mengalami mual muntah. Kira-kira 5\% dari ibu hamil membutuhkan penanganan untuk mengganti cairan dan koreksi ketidakseimbangan elektrolit (Supriyanto, 2009). Dari hasil penelitian Herrel (2014) mengatakan bahwa sekitar $80 \%$ dari wanita melaporkan gejala mual muntah berlangsung sepanjang hari dan $1,8 \%$ melaporkan gejala mual muntah terjadi di pagi hari.

Data menunjukkan bahwa lebih dari $85 \%$ wanita hamil merasa terganggu aktivitasnya karena mual muntah dan mengatasinya dengan mengkonsumsi obat-obatan anti mual. Namun penggunaan obat yang tidak tepat seringkali membahayakan ibu hamil dan janinnya karena diketahui dapat menyebabkan distorsi. Pemberian obat pada wanita hamil yang mengandung efek terapeutik berlebihan kadangkala justru menimbulkan efek toksik baik pada ibu maupun janinnya (Derek dan John, 2002 dalam Pujiastuti, 2014).

Akan tetapi lebih baik jika ibu hamil mampu mengatasi masalah mual muntah pada awal kehamilan dengan menggunakan terapi pelengkap nonfarmakologis dan komplementer terlebih dahulu. Penggunaan terapi pelengkap nonfarmakologis bersifat noninstruktif, noninfasif, murah, sederhana, efektif dan tidak mempunyai efek samping yang merugikan bagi ibu hamil (Santi, 2013). Untuk menghindari adanya efek samping yang ditimbulkan oleh obat-obatan tersebut, maka penatalaksanaan mual muntah juga dapat dilakukan dengan memberikan terapi non farmakologi seperti akupuntur, aromaterapi, pendekatan nutrisional, terapi manipulatif dan pendekatan psikologis (Tiran, 2008).

Salah satu aromaterapi yang sering digunakan ialah peppermint (mentha piperita). Peppermint termasuk dalam marga labiate yang memiliki tingkat keharuman yang sangat tinggi, aroma yang dingin menyegarkan dan bau mentol yang mendalam. Peppermint mengandung khasiat anti kejang dan penyembuhan yang andal untuk kasus mual, salah cerna, susah membuang gas diperut, diare, sembelit, sakit kepala dan pingsan (Zuraida dan Sari, 2017).

Aromaterapi peppermint mengandung menthol (35-45\%) dan menthone (10\%-30\%) sehingga dapat bermanfaat sebagai antiemetik dan antispasmodik pada lapisan lambung dan usus dengan menghambat kontraksi otot yang disebabkan oleh serotonin dan substansi lainnya (Stea, dkk. 2014). Aromaterapi peppermint yang mengandung minyak atsiri menthol memiliki efek karnimatif dan antispasmodik yang bekerja di usus halus pada saluran pencernaan sehingga mampu mengatasi ataupun menghilangkan mual muntah (Tiran, 2008).

Hasil penelitian yang dilakukan oleh Santi (2013) menyatakan bahwa Aromaterapi blended peppermint dan ginger oil dapat mengurangi rasa mual dan muntah pada ibu hamil trimester 1. Menurut penelitian yang dilakukan oleh Sari, dkk (2015) pemberian aromaterapi peppermint dapat menurunkan mual dan muntah akut pada pasien yang menjalani kemoterapi. Hasil penelitian yang dilakukan oleh Siswantoro (2015) menyatakan bahwa bahwa aromaterapi daun mint dapat menurunkan sesak nafas pada pasien tuberculosis paru.

PMB Linda Silalahi merupakan salah satu fasilitas pelayanan kesehatan yang berada di Pancur Batu. Berdasarkan hasil studi pendahuluan yang telah dilakukan oleh peneliti di PMB Linda Silalahi didapatkan ibu hamil yang mengeluhkan mual muntah sebanyak 15 orang. 15 orang ibu hamil tersebut tidak pernah memakai aromaterapi peppermint untuk mengatasi mual muntah. Hal inilah yang membuat peneliti melakukan penelitian di PMB tersebut.

Berdasarkan latar belakang tersebut, maka perlu dilakukan penelitian tentang Pengaruh Pemberian Aromaterapi Minyak Peppermint Secara Inhalasi Terhadap Penurunan Mual Muntah Pada Ibu Hamil di PMB Linda Silalahi J1. Jamin Ginting km.18, Pancur Batu. 


\section{METODE}

Penelitian ini merupakan penelitian Pre eksperimental dengan rancangan penelitian One Group Pretest Posttest Designs. Penelitian dilakukan di PMB Linda Silalahi Jl. Jamin Ginting km.18, Pancur Batu pada bulan Januari sampai dengan Juni 2019. Populasi dalam penelitian adalah seluruh ibu hamil yang datang berkunjung ke PMB Linda Silalahi pada bulan Maret 2019. Teknik sampling yang digunakan pada penelitian ini adalah Purposive Sampling, yaitu metode pengambilan sampel yang didasarkan pada suatu pertimbangan tertentu yang dibuat oleh peneliti sendiri berdasarkan ciri atau sifat-sifat populasi yang diketahui sebelumnya (Notoatmodjo, 2012). Jumlah sampel yang digunakan adalah 15 ibu hamil trimester pertama. Instrumen yang digunakan adalah lembar observasi untuk pemberian aromaterapi minyak peppermint secara inhalasi dan lembar observasi Pregnancy Unique Quantification of Emesis and Nausea (PUQE-24) yaitu sistem penilaian untuk mengukur tingkat keparahan mual muntah kehamilan dalam 24 jam. Karena data berdistribusi tidak normal, maka digunakan analisa data dengan Uji Wilcoxon Sign Rank Test.

\section{HASIL PENELITIAN}

Distribusi frekuensi karakteristik ibu hamil yang diteliti meliputi umur, pendidikan, pekerjaan, usia kehamilan dan status gravida. Karakteristik dari 15 responden ibu hamil dapat dilihat pada table berikut :

Tabel 1: Distribusi frekuensi karakteristik ibu hamil berdasarkan umur, pendidikan, pekerjaan, usia kehamilan dan status gravida

\begin{tabular}{|c|c|c|}
\hline \multirow{2}{*}{ Variabel } & \multicolumn{2}{|c|}{ Total Responden } \\
\hline & $\mathbf{n}$ & $\%$ \\
\hline \multicolumn{3}{|l|}{ Variabel Dependen } \\
\hline \multicolumn{3}{|l|}{ Karakteristik } \\
\hline Umur & 2 & 13,33 \\
\hline$<20$ Tahun & 12 & 80 \\
\hline 20-35 Tahun & 1 & 6,67 \\
\hline Total & 15 & 100 \\
\hline \multicolumn{3}{|l|}{ Pendidikan } \\
\hline SMP & 3 & 20 \\
\hline SMA & 9 & 60 \\
\hline S1 & 3 & 20 \\
\hline Total & 15 & 100 \\
\hline \multicolumn{3}{|l|}{ Pekerjaan } \\
\hline IRT & 12 & 80 \\
\hline PNS & 3 & 20 \\
\hline Total & 15 & 100 \\
\hline Usia Kehamilan & 3 & 20 \\
\hline 6-7 minggu & 1 & 6,67 \\
\hline 7-8 minggu & 4 & 26,67 \\
\hline 8-9 minggu & 2 & 13,33 \\
\hline 9-10 minggu & 2 & 13,33 \\
\hline 10 minggu & 1 & 6,67 \\
\hline 10-11 minggu & 2 & 13,33 \\
\hline \multicolumn{3}{|l|}{$11-12$ minggu } \\
\hline Total & 15 & 100 \\
\hline \multicolumn{3}{|l|}{ Status Gravida } \\
\hline G1P0A0 & 11 & 73,33 \\
\hline G2P1A0 & 4 & 26,67 \\
\hline Total & 15 & 100 \\
\hline
\end{tabular}


Berdasarkan tabel 1 diketahui dari 15 orang ibu hamil trimester pertama mayoritas berusia 20-35 tahun sebanyak 12 orang (80\%), mayoritas ibu hamil berpendidikan SMA sebanyak 9 orang (60\%), mayoritas ibu hamil usia kehamilannya 8-9 minggu sebanyak 4 orang (26,67\%), mayoritas ibu hamil bekerja sebagai Ibu Rumah Tangga sebanyak 12 orang (80\%) dan mayoritas responden belum memiliki anak atau baru pertama kali hamil sebanyak 11 orang $(73,33 \%)$.

\section{Analisa Univariat}

Analisa ini bertujuan untuk melihat distribusi frekuensi mual muntah pada ibu hamil sebelum dan sesudah dilakukan pemberian aromaterapi minyak peppermint secara inhalasi. Hasil analisa univariat dapat dilihat pada tabel 2 berikut :

Tabel 2: Distribusi skor mual muntah sebelum dan sesudah pemberian aromaterapi minyak peppermint secara inhalasi pada ibu hamil

\begin{tabular}{ccccc}
\hline $\begin{array}{c}\text { Interpretasi } \\
\text { Skor Mual Muntah }\end{array}$ & Sebelum & \multicolumn{2}{c}{ Sesudah } \\
\cline { 2 - 5 } & F & $\%$ & F & $\%$ \\
$\mathbf{3}$ & 0 & 0 & 12 & 80 \\
$\mathbf{4 - 7}$ & 0 & 0 & 3 & 20 \\
$\mathbf{8 - 1 1}$ & 12 & 80 & 0 & 0 \\
$\mathbf{1 2 - 1 5}$ & 3 & 20 & 0 & 0 \\
\hline Total & $\mathbf{1 5}$ & $\mathbf{1 0 0}$ & $\mathbf{1 5}$ & $\mathbf{1 0 0}$ \\
\hline
\end{tabular}

Berdasarkan tabel 2 menunjukkan distribusi skor mual muntah sebelum dan sesudah dilakukan pemberian aromaterapi minyak peppermint secara inhalasi pada ibu hamil. Skor mual muntah ibu hamil sebelum dilakukan pemberian aromaterapi minyak peppermint secara inhalasi adalah 8-11 dengan jumlah ibu hamil yang mengalami mual muntah sedang sebanyak 12 orang (80\%), sedangkan skor mual muntah ibu hamil setelah dilakukan pemberian aromaterapi minyak peppermint secara inhalasi adalah 3 dengan jumlah ibu hamil tidak muntah sebanyak 12 orang $(80 \%)$.

\section{Analisa Bivariat}

Analisis yang digunakan pada penelitian ini adalah Wilcoxon Sign Rank Test dengan derajat kepercayaan $95 \%$ yang bertujuan untuk mengetahui adanya perbedaan skor mual muntah ibu hamil sebelum dan sesudah pemberian aromaterapi minyak peppermint secara inhalasi. Berdasarkan hasil uji statistik diperoleh nilai signifikansi $\mathrm{p}$, untuk nilai $p<0,05$ berarti Ho ditolak atau hipotesis penelitian diterima. Hasil analisa bivariat dapat dilihat pada tabel 3 :

Tabel 3: Distribusi frekuensi rata-rata skor mual muntah sebelum dan sesudah pemberian aromaterapi minyak peppermint secara inhalasi pada ibu hamil 


\begin{tabular}{lcccc}
\hline Kelompok & Mean & SD & $\begin{array}{c}\text { Beda } \\
\text { Mean }\end{array}$ & $\mathbf{p}$ \\
\hline Sebelum & & & & \\
Sesudah & 9,80 & 1,521 & 6,13 & 0,001 \\
\end{tabular}

Berdasarkan tabel di atas, dapat diketahui rata-rata (mean) skor mual muntah ibu hamil sebelum diberikan aromaterapi minyak peppermint secara inhalasi (pretest) sebesar 9,80 dan standar deviasi sebesar 1,521. Pada pengukuran sesudah diberikan aromaterapi minyak peppermint secara inhalasi (posttest) diperoleh rata-rata (mean) sebesar 3,67 dan standar deviasi sebesar 1,397. Terjadi penurunan rata-rata skor mual muntah sebelum dan sesudah pemberian aromaterapi minyak peppermint secara inhalasi sebesar 6,13 dengan standar deviasi 0,124. Dari hasil uji Wilcoxon Sign Rank Test terdapat perbedaan nilai rata-rata (mean) skor mual muntah ibu hamil sebelum dan sesudah pemberian aromaterapi minyak peppermint secara inhalasi. Jadi dapat dinyatakan bahwa ada pengaruh pemberian aromaterapi minyak peppermint secara inhalasi terhadap penurunan mual muntah pada ibu hamil

\section{PEMBAHASAN}

Hasil penelitian menunjukkan bahwa sebagian besar responden berusia 20-35 tahun sebanyak 12 orang (80\%). Beberapa penelitian menyebutkan bahwa semakin tua usia seseorang maka, semakin jarang dia akan mengalami mual muntah. Hal ini disebabkan karena yang berusia tua telah mempunyai pengalaman dalam mengatasi mual muntah, sedangkan pada usia muda belum mampu mengatasi mual muntah karena sebagian besar merupakan kehamilan pertama (Putri, dkk, 2016).

Berdasarkan karakteristik pendidikan sebagian besar responden berpendidikan SMA sebanyak 9 orang $(60 \%)$. Tingkat pendidikan berhubungan dengan kemampuan menerima informasi kesehatan dari media massa dan petugas kesehatan (Tiran, 2018).

Berdasarkan karakteristik usia kehamilan sebagian besar ibu hamil mempunyai usia kehamilan 8-9 minggu sebanyak 4 orang $(26,67 \%)$. Beberapa penelitian menyebutkan bahwa semakin tua usia kehamilan seseorang maka, semakin jarang dia akan mengalami mual muntah. Setelah usia kehamilan menginjak 12 minggu gejala-gejala itu biasanya menghilang karena tubuh ibu sudah menyesuaikan diri dengan perubahan yang terjadi selama masa kehamilan (Sukmawati, dkk, 2018).

Hasil penelitian menunjukkan bahwa sebagian besar pekerjaan responden adalah Ibu Rumah Tangga sebanyak 12 orang (80\%). Pada wanita hamil yang berada diantara keluarga atau dalam rutinitas kerja, kecemasan terhadap situasi keuangan saat ini dan yang akan datang dapat menyebabkan kekhawatiran tambahan yang membuatnya merasa tidak sehat. Jadi dengan pekerjaan sebagai ibu rumah tangga yang tidak dapat membantu perekonomian keluarga dapat menyebabkan kekhawatiran tambahan yang membuat Ibu hamil merasa tidak sehat sehingga menimbulkan mual muntah pada kehamilannya (Tiran, 2018).

Sebagian besar responden belum memiliki anak dan merupakan kehamilan yang pertama yaitu sebanyak 11 orang $(73,33 \%)$. Gravida juga dapat mempengaruhi kejadian mual muntah. Sesuai dengan teori Tiran (2018) terjadi peningkatan mual muntah pada perempuan yang baru pertama kali mengalami kehamilan (Primigravida) dibanding perempuan yang telah beberapa kali mengalami kehamilan (Multigravida). Hal ini disebabkan karena pada sebagian besar primigravida belum mampu beradaptasi dengan hormon estrogen dan HCG sehingga lebih sering terjadi mual muntah dalam kehamilan. 
Sedangkan pada multigravida dan grandemultigravida sudah mampu beradaptasi dengan hormon estrogen dan HCG karena sudah mempunyai pengalaman terhadap kehamilan dan persalinan. Pada primigravida menunjukkan kurangnya pengetahuan, informasi dan komunikasi yang buruk antara wanita dan pemberi asuhannya turut mempengaruhi persepsi wanita tentang gejala mual muntah. Sedangkan pada multigravida dan grandemultigravida sudah mempunyai pengalaman, informasi dan pengetahuan tentang gejala mual muntah pada kehamilan sehingga mampu mengatasi gejalanya.

Hasil penelitian ini menunjukkan bahwa sebelum diberikan aromaterapi minyak peppermint secara inhalasi, ibu hamil yang mengalami mual muntah sedang sebanyak 12 orang dan yang mengalami mual muntah berat sebanyak 3 orang. Setelah diberikan aromaterapi minyak peppermint secara inhalasi, ibu hamil yang tidak muntah sebanyak 12 orang dan yang mengalami mual muntah ringan sebanyak 3 orang.

Berdasarkan hasil penelitian didapatkan bahwa nilai rata-rata mual muntah sebelum diberikan aromaterapi minyak peppermint secara inhalasi sebesar 9,80 dan setelah diberikan aromaterapi minyak peppermint secara inhalasi didapatkan nilai rata-rata mual muntah sebesar 3,67. Perbedaan nilai mean sebesar 6,13 . Nilai signifikansi $p$ sebesar $0,001(p<0,05)$ yang artinya terdapat perbedaan nilai rata-rata (mean) skor mual muntah ibu hamil sebelum dan sesudah pemberian aromaterapi minyak peppermint secara inhalasi. Data tersebut menunjukkan bahwa pemberian aromaterapi minyak peppermint secara inhalasi memberikan pengaruh yang signifikan terhadap penurunan mual muntah pada ibu hamil.

Dari uraian diatas maka hipotesa penelitian dapat dijawab dimana $\mathrm{H} 1$ diterima karena terdapat penurunan skor mual muntah pada ibu hamil setelah diberikan aromaterapi minyak peppermint secara inhalasi, sehingga dapat disimpulkan bahwa pemberian aromaterapi minyak peppermint secara inhalasi berpengaruh dalam menurunkan mual muntah pada ibu hamil.

Penelitian ini didukung oleh Sari, dkk (2015), tentang Pengaruh Aromaterapi Peppermint terhadap Penurunan Mual dan Muntah Akut Pada Pasien yang Menjalani Kemoterapi di SMC RS Telogorejo. Hasil penelitian ini menunjukkan bahwa jumlah responden yang mengalami mual dan muntah ringan sebelum diberikan aromaterapi peppermint adalah sebesar 53,3\% dan mengalami mual dan muntah sedang sebesar 46,7\%. Jumlah responden yang mengalami mual muntah ringan setelah diberikan aromaterapi peppermint terjadi peningkatan dengan persentase $86,7 \%$ sedangkan yang mengalami mual muntah sedang terjadi penurunan dengan persentase $13,3 \%$, sehingga dapat disimpulkan ada pengaruh yang bermakna pemberian aromaterapi peppermint terhadap penurunan mual dan muntah akut pada pasien yang menjalani kemoterapi di SMC RS Telogorejo $(p=0,000)$.

Penelitian ini juga sejalan dengan penelitian yang dilakukan oleh Santi (2013) tentang Pengaruh Aromaterapi Blended Peppermint dan Ginger Oil terhadap Rasa Mual pada Ibu Hamil Trimester Satu di Puskesmas Rengel Kabupaten Tuban. Hasil penelitian menemukan bahwa berdasarkan analisis data dengan menggunakan Uji Wilcoxon Sign Rank Test dengan tingkat kemaknaan $\alpha=0,05$, diperoleh nilai $\mathrm{p}=0,001(\mathrm{p}<0,05)$ maka H1 diterima dan H0 ditolak, sehingga dapat disimpulkan ada pengaruh yang bermakna pemberian aromaterapi blended peppermint dan ginger oil terhadap rasa mual pada ibu hamil trimester 1 di Puskesmas Rengel Kabupaten Tuban.

Menurut penelitian lain yang dilakukan oleh Zuraida dan Sari (2017) tentang Perbedaan Efektifitas Pemberian Essensial Oil Peppermint dan Aromaterapi Lavender Terhadap Intensitas Mual dan Muntah Pada Ibu Hamil Trimester I di Puskesmas Baso Kabupaten Agam menemukan bahwa terjadi penurunan intensitas mual muntah pada ibu hamil setelah pemberian 
Essensial Oil Peppermint dan Aromaterapi Lavender, dimana setelah pemberian Essensial Oil Peppermint terjadi penurunan rata-rata intensitas mual muntah pada ibu hamil trimester I sebesar 5,42 dan setelah pemberian Aromaterapi Lavender terjadi penurunan rata-rata intensitas mual muntah pada ibu hamil trimester I sebesar 3,28. Terdapat perbedaan efektifitas pemberian Essensial Oil Peppermint dan Aromaterapi Lavender terhadap penurunan intensitas mual muntah pada ibu hamil trimester I dengan perbedaan rata-rata penurunan sebesar 2,14 dan nilai $\mathrm{p}=0,001$. Jadi dapat disimpulkan pemberian Essensial Oil Peppermint lebih efektif dalam penurunan mual muntah pada ibu hamil trimester I.

Hasil penelitian ini juga sesuai dengan teori Tiran (2018), mual muntah merupakan salah satu gejala paling awal, paling umum dan paling menyebabkan stress yang dikaitkan dengan kehamilan. Mual muntah seringkali diabaikan karena dianggap sebagai sebuah konsekuensi normal diawal kehamilan tanpa mengakui dampak hebat yang ditimbulkannya pada wanita dan keluarga mereka. Bagi beberapa wanita, gejala dapat berlangsung sepanjang hari atau mungkin tidak terjadi sama sekali pada saat bangun tidur dipagi hari. Mual muntah selama kehamilan biasanya disebabkan oleh perubahan dalam sistem endokrin yang terjadi selama kehamilan, terutama disebabkan oleh tingginya fluktasi kadar HCG, khususnya karena periode mual muntah gestasional yang paling umum adalah pada 12-16 minggu pertama, yang pada saat itu HCG mencapai kadar tingginya.

Peppermint termasuk dalam marga labiate, yaitu memiliki tingkat keharuman yang sangat tinggi, aroma yang dingin menyegarkan dan bau mentol yang mendalam. Peppermint mengandung khasiat anti kejang dan penyembuhan yang andal untuk kasus mual, salah cerna, susah membuang gas diperut, diare, sembelit, flu, sakit kepala, migrain dan pingsan (Zuraida dan Sari, 2017).

Penelitian ini sesuai dengan pernyataan Stea, dkk, (2014) bahwa aromaterapi peppermint mengandung menthol (35-45\%) dan menthone (10\%-30\%) sehingga dapat bermanfaat sebagai antiemetik dan antispasmodik pada lapisan lambung dan usus dengan menghambat kontraksi otot yang disebabkan oleh serotonin dan substansi lainnya. Aromaterapi peppermint yang mengandung minyak atsiri menthol memiliki efek karnimatif dan antispasmodik yang bekerja di usus halus pada saluran pencernaan sehingga mampu mengatasi ataupun menghilangkan mual muntah (Tiran, 2008).

Menurut asumsi peneliti setelah melakukan pemberian aromaterapi minyak peppermint secara inhalasi, skor mual muntah pada ibu hamil akan semakin menurun karena peppermint mengandung menthol dan menthone yang dapat bermanfaat sebagai antiemetik dan antispasmodik pada lapisan lambung dan usus sehingga mampu mengatasi ataupun menghilangkan mual muntah pada ibu hamil. Ibu hamil yang tidak menggunakan aromaterapi minyak peppermint secara inhalasi akan lebih sering mengalami mual muntah. Dimana mual muntah disebabkan oleh perubahan pada sistem endokrin yang terjadi selama kehamilan, terutama disebabkan oleh tingginya fluktuasi kadar HCG, khususnya pada periode mual muntah gestasional yang paling umum terjadi adalah pada 12-16 minggu pertama.

Peppermint juga mempunyai kandungan minyak atsiri yang dapat berfungsi sebagai karminatif, antimikroba dan antivirus. Maka dapat disimpulkan bahwa pemberian Aromaterapi Minyak Peppermint secara Inhalasi berpengaruh dalam penurunan mual muntah pada ibu hamil.

\section{KESIMPULAN DAN SARAN}

\section{Kesimpulan}


Berdasarkan hasil penelitian tentang Pengaruh Pemberian Aromaterapi Minyak Peppermint Secara Inhalasi terhadap Penurunan Mual Muntah Pada Ibu Hamil di PMB Linda Silalahi Pancur Batu Tahun 2019 dapat ditarik kesimpulan sebagai berikut :

1. Sebelum dilakukan pemberian aromaterapi minyak peppermint secara inhalasi mayoritas ibu hamil termasuk dalam kategori mual muntah sedang sebanyak 12 orang $(80 \%)$. Setelah dilakukan pemberian aromaterapi minyak peppermint secara inhalasi mayoritas ibu hamil termasuk dalam kategori tidak muntah sebanyak 12 orang $(80 \%)$.

2. Rata-rata skor mual muntah ibu hamil sebelum diberikan aromaterapi minyak peppermint secara inhalasi yaitu sebesar 9,80 dan rata-rata skor mual muntah ibu hamil setelah diberikan aromaterapi minyak peppermint secara inhalasi yaitu sebesar 3,67 dengan penurunan rata-rata 6,13. Hasil uji statistik Wilcoxon Sign Rank Test didapatkan nilai $\mathrm{p}$ value $0,001<0,05(\mathrm{p}<0,05)$ sehingga dapat disimpulkan bahwa pemberian aromaterapi minyak peppermint secara inhalasi berpengaruh dalam penurunan mual muntah pada ibu hamil.

\section{Saran}

Kepada Bidan yang bertugas di PMB Linda Silalahi disarankan untuk memberikan Aromaterapi Minyak Peppermint Secara Inhalasi terhadap Penurunan Mual Muntah

\section{DAFTAR PUSTAKA}

Anasari, T. 2012. Beberapa Determinan Penyebab Kejadian Hiperemesis Gravidarum di RSU Ananda Purwokerto Tahun 2009-2011. Jurnal Involusi Kebidanan. Vol. 2 No. 4.

Ayuningtyas, I. F. 2019. Terapi Komplementer dalam Kebidanan. Yogyakarta : Pustaka Baru Press.

Badan Penelitian dan Pengembangan Kesehatan Kementerian Kesehatan RI. 2013. Riskesdas $2013 . \quad$ http://www.google.com/url?sa=t\&source=web \&rct=j\&url=http://www.depkes.go.id/resources/download/general/Hasil\%2520Riskesda s\%25202013.pdf (diakses tanggal 17 Januari 2019).

Dinas Kesehatan Kota Medan. 2016. Profil Kesehatan Kota Medan 2016. https://www.google.com/url?sa=t\&source=web\&rct=j\&url=http://www.depkes.go.id/re sources/download/profil/PROFIL_KAB_KOTA_2016/1275_Sumut_Kota_Medan_201 6.pdf (diakses tanggal 17 Januari 2019).

Eniyanti dan Devi. 2017. Sikap Ibu Hamil dalam Menghadapi Ketidaknyamanan Kehamilan Trimester I di Puskesmas Bantul Yogyakarta. Jurnal Kesehatan Samudra Ilmu. Vol. 08 No.1.

Farrer, H. 2001. Perawatan Maternitas. Edisi Kedua. Jakarta : EGC.

Khasanah, P.N. 2017. Hubungan Tingkat Stress dengan Kejadian Emesis Gravidarum Pada Ibu Hamil Trimester I di Wilayah Kerja Puskesmas I Cilongok Kabupaten Banyumas. Skripsi. Program Studi Ilmu Keperawatan Fakultas Ilmu Kesehatan Universitas Muhammadiyah Purwokerto. Purwokerto.

Notoatmodjo, S. 2012. Metodologi Penelitian Kesehatan. Jakarta : Rineka Cipta.

Prawirohardjo, S. 2005. Ilmu Kebidanan. Jakarta : Bina Pustaka Sarwono Prawirohardjo 2009. Ilmu Kebidanan. Jakarta : Bina Pustaka Sarwono Prawirohardjo

Pujiastuti, E. 2014. Pengaruh Ekstrak Rimpang Jahe Merah (Zingiber officinale var. Rubrum) Terhadap Perkembangan Embrio Praimplantasi Mencit (Mus musculus) Swiss Webster. Skripsi. Program Studi Biologi Fakultas Pendidikan Matematika dan Ilmu Pengetahuan Alam Universitas Pendidikan Indonesia.

Putri, Andiani dan Haniarti. 2016. Efektivitas Pemberian Jahe Hangat dalam Mengurangi Frekuensi Mual Muntah Ibu Hamil Trimester I. Prosiding Seminar Nasional IKAKESMADA "Peran Tenaga Kesehatan dalam Pelaksanaan SDGs" 
Santi, D.R. 2013. Pengaruh Aromaterapi Blended Peppermint dan Ginger Oil Terhadap Rasa Mual Pada Ibu Hamil Trimester Satu di Puskesmas Rengel Kabupaten Tuban. Jurnal Sain Med. Vol. 5 No.2.

Sari Rinda Intan, dkk. 2015. Pengaruh Aromaterapi Peppermint Terhadap Penurunan Mual Muntah Akut Pada Pasien yang Menjalani Kemoterapi di SMC RS Telogorejo. Jurnal Ilmu Keperawatan dan Kebidanan. Vol.III No.2.

Siswantoro, E. 2015. Pengaruh Aromaterapi Daun Mint dengan Inhalasi Sederhana Terhadap Penurunan Sesak Nafas Pada Pasien Tuberculosis Paru. Jurnal Keperawatan dan Kebidanan

Stea, dkk. 2014. Essential Oils For Complementary Treatment Of Surgical Patients : State Of the Art.http://www.hindawi.com/journals/ecam / 2014 / 72634 (diakses tanggal 15 Januari 2019)

Sukmawati Ellyzabeth, dkk. 2018. Farmakologi Kebidanan. Jakarta : CV. Trans Info Media.

Supriyanto. 2009. Faktor Predisposisi Kejadian Emesis Pada Ibu Hamil Trimester I di RB YK WP Tahun 2010. http:// digilib. unimus. ac.id /download.php?=682 (diakses tanggal 14 Januari 2019).

Tiran, D. 2018. Mual dan Muntah Kehamilan. Jakarta : EGC.

Zuraida dan Sari, E.D. 2017. Perbedaan Efektifitas Pemberian Essensial Oil Peppermint dan Aromaterapi Lavender Terhadap Intensitas Mual dan Muntah Pada Ibu Hamil Trimester I di Puskesmas Baso Kabupaten Agam Tahun 2017. Jurnal Menara ilmu. Vol. XII No. 4. 